\title{
岩手医科大学歯学部口腔外科における外来診療の実態について
}

一一特に昭和 44 年 1 月より昭和 45 年 6 月に至る 1 年 6 カ月の臨床統計的観察—

\author{
小川邦明・藤岡幸雄 $\cdot$ 大橋 靖 ・関山三郎 $・$ 工藤啓吾 \\ 本間隆義・玉木功一・青村修明
}

\section{Clinico-statistical observation of the outpatient}

\author{
Department of oral surgery, School of Dentistry, Iwate Medical University \\ during the period between january 1969 and june 1970
}

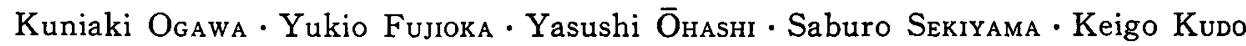
Takayoshi Honma $\cdot$ Kouichi TAMAKI $\cdot$ Nobuaki Aomura
\end{abstract}

緒言

岩手医科大学齿学部付属病院口腔外科は昭和 40 年 4 月に開設され，丁度満 5 年を経過したことになる. 当 科は東北地方に括ける，最初の歯育機関の口䐁外科尃門 診施設として発足したわけであって, この 5 年間に括け る療診療の動態を調査することは，当地方に拈ける口䐁 外科的診療対象の実態を知るらえで，きわめて有用なも のと考えられる. 以上の観点に立って，創立より 5 年間 にわたる当科に打ける診療の実態を整理, 分析したので あるが，このうち入院患者の動態については，すでに第 24 回日本口腔科学会総会に执いて報告した ${ }^{1}$.

今回は外来㭧者について同様の集計を行ない，特に昭 和 44 年1月上り昭和 45 年 6 月洷る 1 年 6 力月間比 ついて, 新来患者の診断別, 月別頻度について調査し, さらに地域別受診状態などの臨床統計的検討を行なった ので, その概要を報告したい.

\section{調 查 成 績}

\section{I. 口腔外科外来患者の動態}

\section{1. 患者数}

新来患者数：昭和 40 年 1 月より昭和 45 年 6 月まで 飞，当科外来を受診した新来の患者総数は 14,621 名で，

岩手医科大学歯学部口腔外科（主任：藤岡幸堆教授，大橋䇌 教授)

Iwate Medical University, School of Dentistry, Department of Oral Surgery

(Chief; Prof. Yukio Fujioka, Prof. Yasushi Ohashi)

受付 昭和 46 年 6 月 26 日
各年度に括ける患者数は図 1 亿示すようにほぼ平均して いた. そのうち昭和 44 年 1 月より昭和 45 年 6 月まで の 1 年 6 力月間についてみると，新来患者数は 4,276 名 であった.

再来患者数再来患者数炕つては，昭和 44 年度は不 明な部分が多くて集計できなかったが，昭和 41 年より 同 45 年 6 月までの集計では 61,072 名で, 各年度にお ける頻度は図1に示すごとくほぼ平均していた。また昭 和 44 年 1 月より昭和 45 年 6 月までの 1 年 6 力月間の

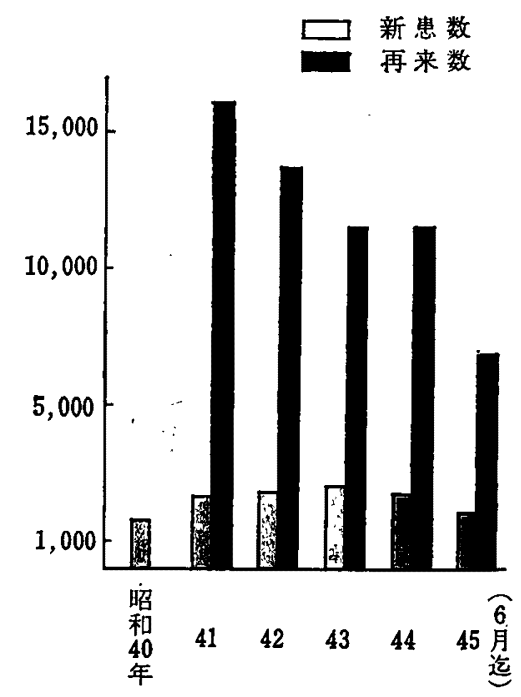

図 1 年度別外来患者数 
再来患者数は，総計 18,536 名であった。

\section{2. 性年令別}

昭和 45 年 1 月より 6 月にいたる 6 カ月間の新来患者 1,493 名について, 性, 年令別頻度を調査したものが図 2であるが，性別ではそれほどの差はなく，わずかに 20 代打よび 40 代の女性に多くみられた．年令別では 20 代 でピークを示し，20才から40才代までの壮年層におい て最も多くなっていたこのことは後述するように，当 口腔外科の外来診療の対象として，雪性炎症が高い頻度 を占めていたためと思われる。

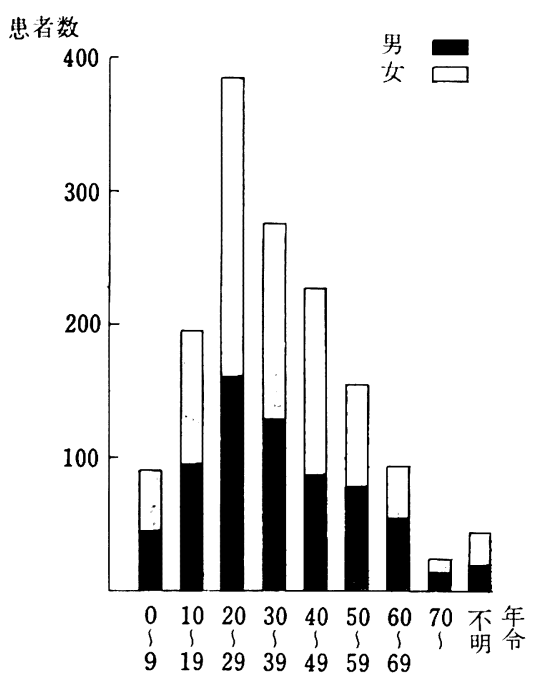

図 2 昭和 45 年性年令別新患数

\section{3. 月別頻度}

昭和 40 年より昭和 45 年月までの, 新来患者および 再来患者を月別頻度で見たものが，図 3 扎よび 4 である. 新来患者については，各月ともに差がほとんど認められ ないのに比べて，再来患者では $1,2,3$ 月および 8 月の 来科数が多く，当地方が農村地带であることを考虑する ならば,これらの月が丁度農閑期に一致している点から

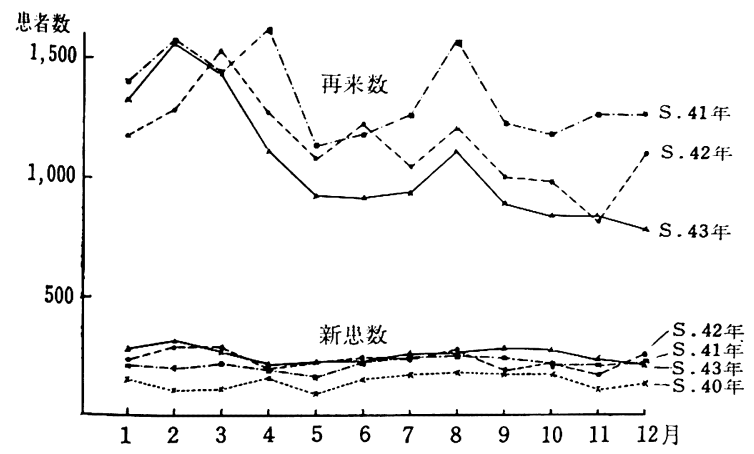

图 3 その 1 月別新患. 再来数 (S. 40 年 S. 43 年)

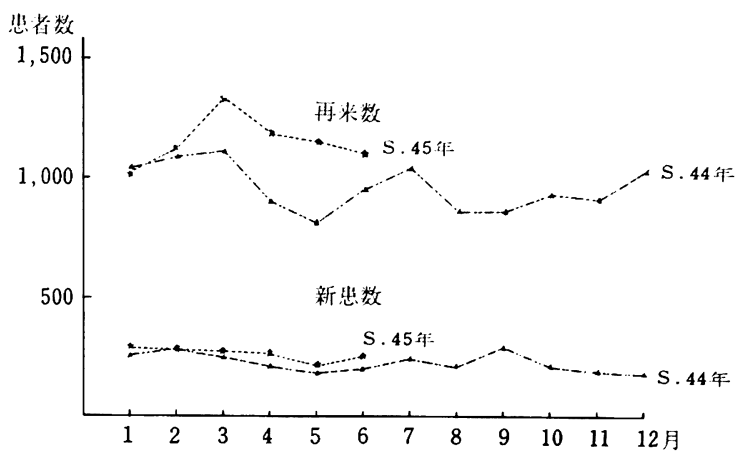

図 4 その 2 月別新乘・再来数 (S. 44 年 S. 45 年 6 月)

みて, 当口然外科の実態が良く示されているものと思わ れる,

また 45 年における再来数の增加は, 同年 2 月より開 始された米学部最高学年の臨床実習において, 経過の観 察を敩重に履修させている結果にもとづくものと考えら れる。

\section{4. 診断別頻度}

昭和 44 年初めから 45 年 6 月までの 1 年 6 カ月間に おいて，新来患者について主訴に対する診断別の分類を 行ない，それに基ついてその頻度を示したものが，表 1 および 2 である。これによると歯牙支持組織疾患とそれ から波及したいわゆる歯性炎症の患者が最も多く, 3, 247 名で全体の約 $76 \%$ を占めており，非常に注目された。

その他のものとしては, 外侸, 奇形, 埋伏崡を含む萠 出異常などが高い頻度を占めていた。ついで，程胞は 107 例で $2.5 \%$ ，良性腫演は 54 例で 1.3\%，悪性腫瘍 は 24 例で $0.6 \%$ であった. その他のものとしては，表 3のような疾患が認められた。なお全体としては，約 $0.5 \%$ に相当して記載不充分なための分類不能例があっ た。

\section{表 1}

診断別頻度（その1）

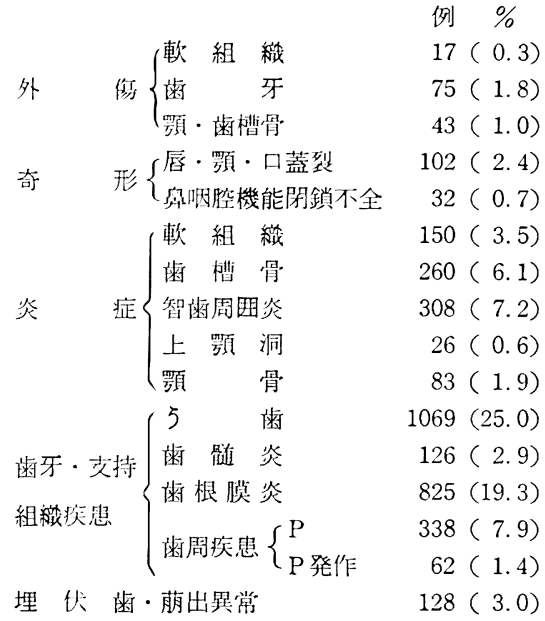


表 2

讋断別頻度（その 2 )

\begin{tabular}{|c|c|c|c|}
\hline & 例 & $\%$ \\
\hline \multirow{4}{*}{ 拔歯後異常 } & (出 & 8( & $0.2)$ \\
\hline & 痛 & 11( & $0.3)$ \\
\hline & 治痛不全 & 50( & 1.2) \\
\hline & 感 染 症 & 25( & $0.6)$ \\
\hline 胞 & & 107( & 2.5) \\
\hline 娥 & 良性腫場 & 54( & 1.3) \\
\hline 䤚 & 恶性連序 & 24( & $0.6)$ \\
\hline 口腔粘膜疾， & & 74( & 1.7) \\
\hline 袮㾑性溃浣 & & $26 C$ & $0.6)$ \\
\hline 潾肉炎 & & 21( & $0.5)$ \\
\hline 舌 炎 & & 13( & $0.3)$ \\
\hline 面 関節症 & & 52( & 1.2) \\
\hline 神経疾患 & & 17( & $0.4)$ \\
\hline その 他 & & 150( & $3.5)$ \\
\hline
\end{tabular}

表 3

診断別頻度 (その 3 )

その他

エプーリス

小带異常

10

唾液腺疾患

变形

外歯 琹

血液疾患

知覚異常

マルファン症候群

プラマーヴンソン症候群

その他

67
150

\section{5. 診断名と月別との関係}

1) 外 傷

䫇骨々折および齿槽骨々折では, 昭和 44 年の 8 月が 最も多くてピーク状を示しており，ついで1月が多かっ たが，その他はほぼ平均した受診状態であった。

2) 奇 形

奇形においてもほぼ平均した来院数を示しているが，

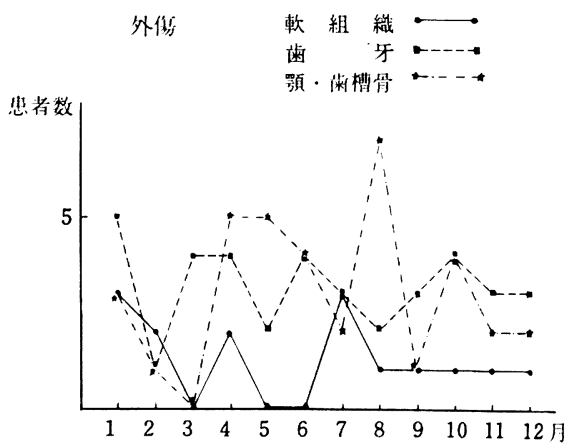

図 5

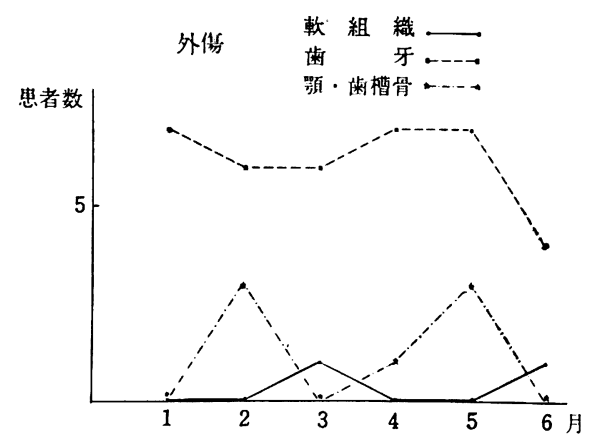

図 6

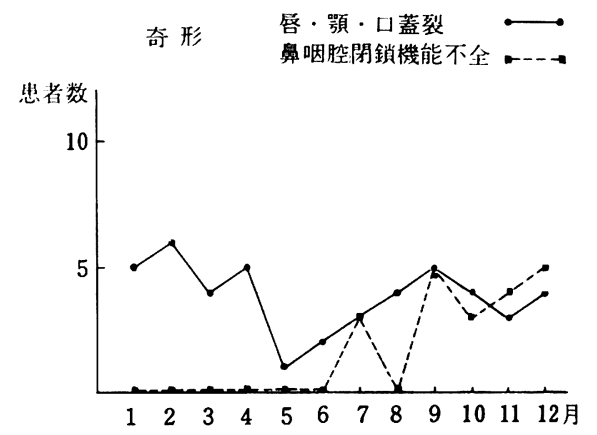

図 7

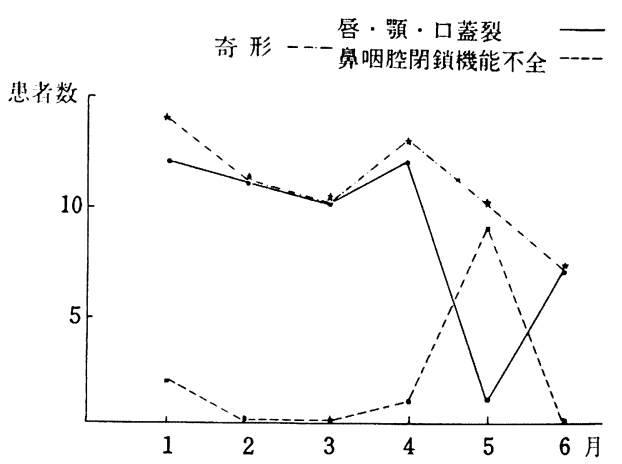

图 8

44 年から䅡極的に開始した舆咽腔閉鎖不全に対する診 断と治療に応じて，他家より診断を依頼されて来院する 患者が， 7 月以降には增加している傾向がみられる.

3) 炎 症

炎症群では全体的にみて，真冬沶よび真夏に多く，他 科に打けるものと同様な傾向を示している，炎症群のう ちとくに智隶周团炎についてみると，1月と 8 月が非常 に多くなっている.

\section{4）歯牙支持組織炎}

ら蝕歯のために抜歯の適応であった症例が最も多く”， これらは農閉期にほぼ集中していた。このことは，先に 述べた当大学の立地条件による特殊性のためと思われる. 


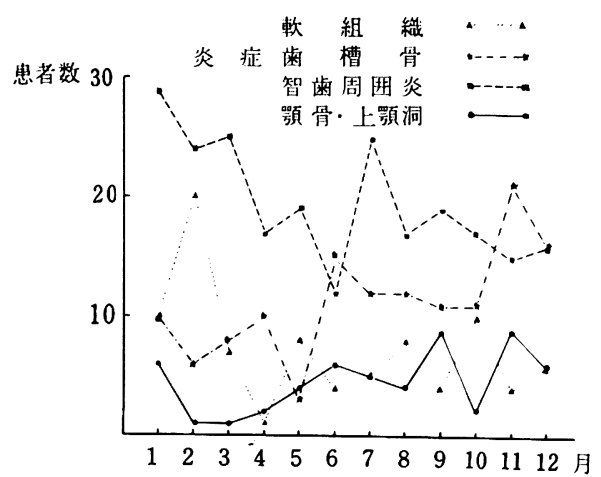

図 9

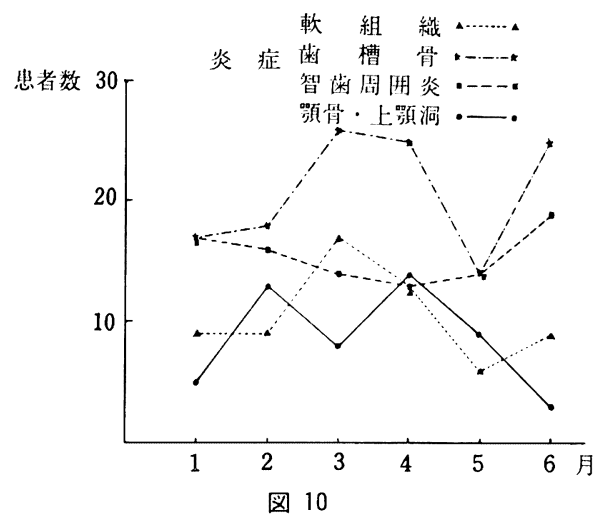

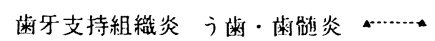
歯根膜炎

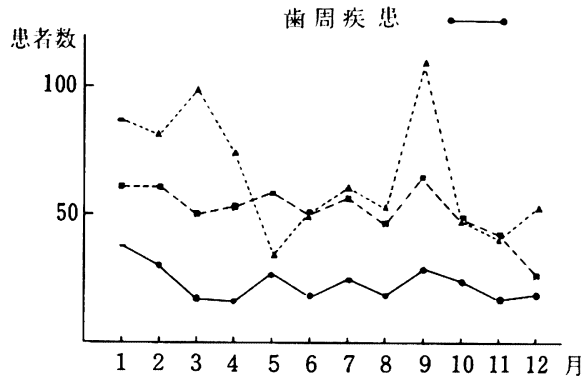

図 11

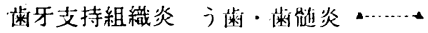

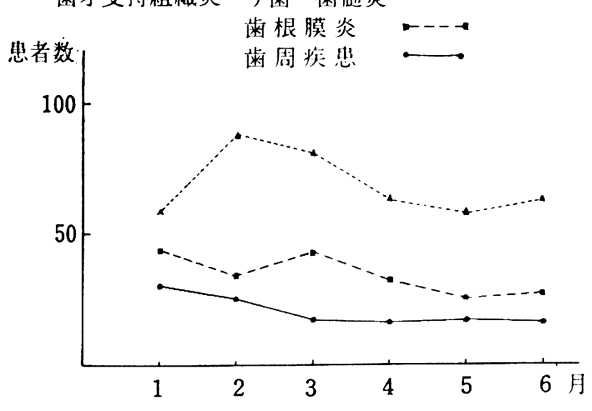

図 12

\section{5）腫瘍}

腫煬については，良性および悪性のものがともにほぼ 平均した受診状態を示していた。

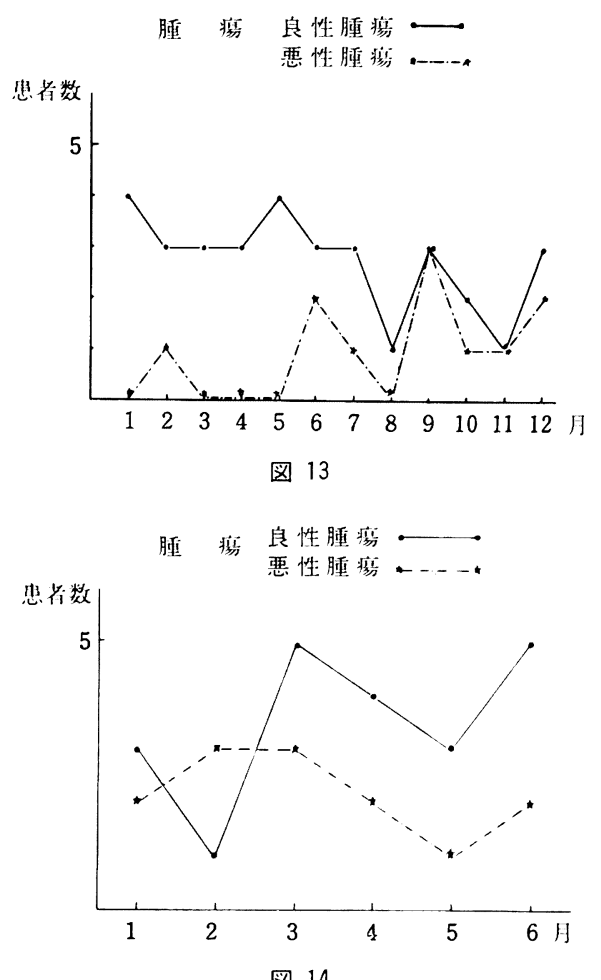

図 14

\section{II. 口腔外科外来患者の地域別受診状態}

岩手県に㧍ける保健所の各ブロックは，図 15 のよう に7つに分けられているが，歯科医们の分布状態は県庁 所在地である盛岡市に集中している。これらのブロック からそれぞれ当科を受診した状態は，図 16 のごとくで ある（な抗これらの集計においては，住所の明確でない ものについては除外した)。これについてみると, 盛岡 市近郊よりの患者が最も多く, 盛岡, 岩手ブロックのみ で $82.4 \%$ の多数を占めており, ついで花㥕, 北上ブロ ックにおける $3.1 \%$ であった。 注目されるのは県南地 方の一関・大東ブロックで，7ブロックのらち最も少 なかったが，この点は宮城県との位置的関係を無視する ことが出来ないものと思われる.

また県外からは 112 人 $(4.3 \%)$ で，比较的多く当科 を受診しており，しかも次第に上年の傾向がみられる. その中で青森県, 秋田県からの受診患者が多かったのは, 歯学総合診療㙨関が東北では仙台, 盛風に所在している ためで，単に岩手㝥地方のみを対象とした施設ではなく， 岩手, 秋田, 青森を含めた北柬北地方全体の施設として, 将来とも考えていかなければならないものと思われる. 


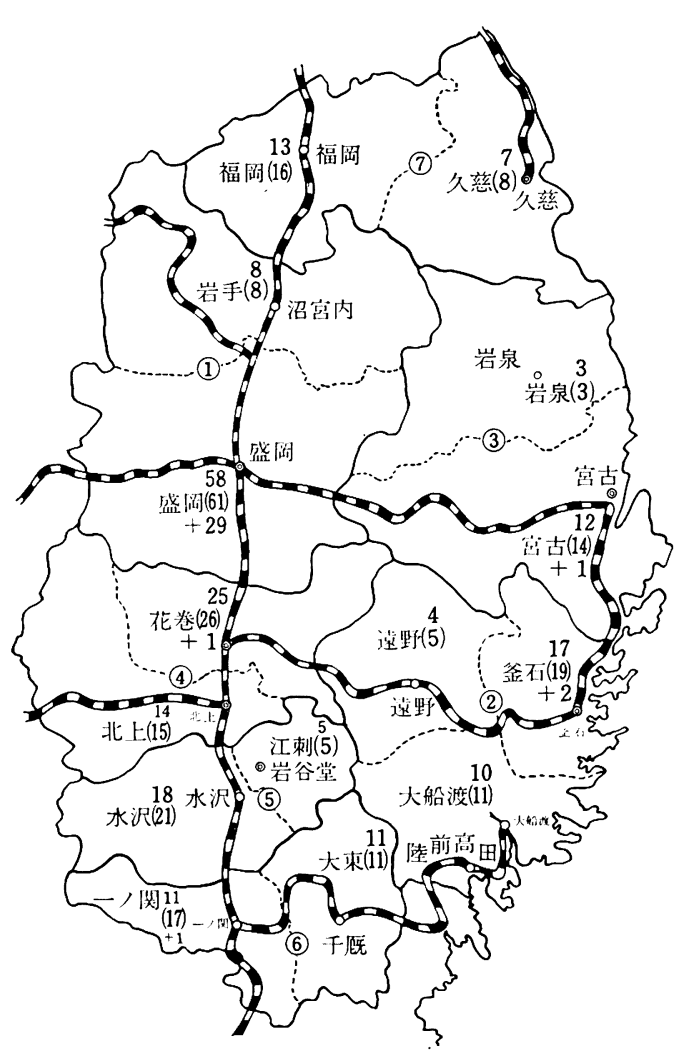

図 15 各地域の上数字は雨科施設数 （）内は歯科医印数＋は勤務医

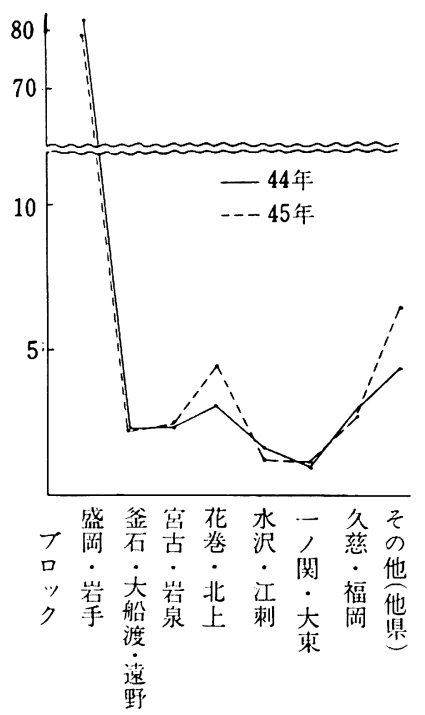

図 16 保健所ブロック別来科綮

盛凧岩手ブロックについて，月别にこれをみてみると 図 17 のように盛岡では 1〜3 月がやや多い程度で, 全

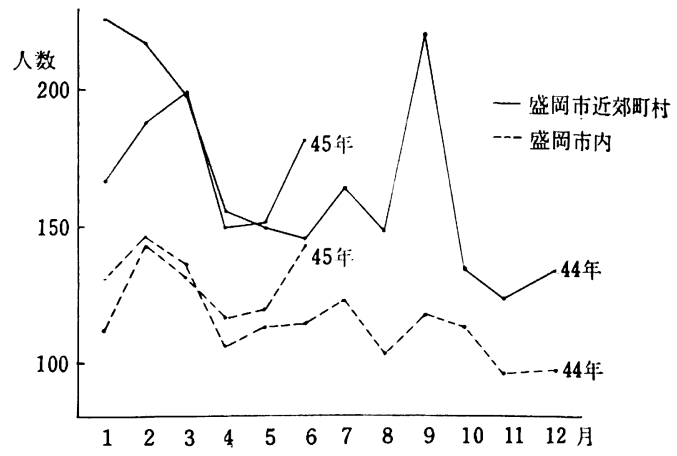

図 17 月別来院患者数

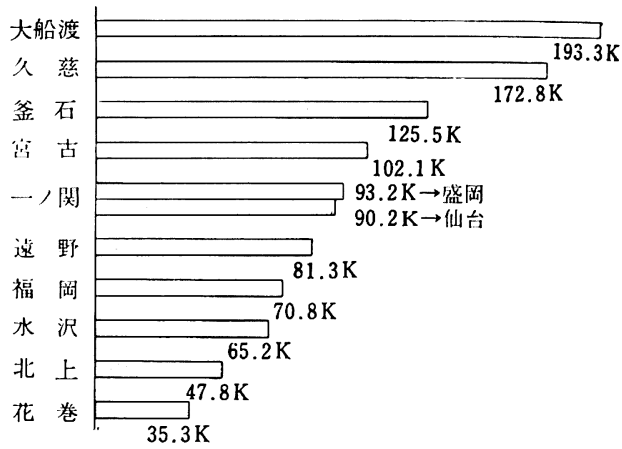

図 18 各ブロックより盛岡までの距㸚数

体的には平均していたのに反し，近郊町村では 1〜3 月 と他の月ではかなりの相違がみられた。このことは当地 方が農村地央であることから，農閑期に相当する $1 〜 3$ 月に受診率が高かったものと思われる。な招 9 月にもか なりの上年がみられたが，これは学校検診後の集団治療 がこのときに行なわれたためである.

地域的条件についてみると盛岡市内が圧倒的に多かっ たが，各保健所ブロックより盛岡までの距離は約 $35 \mathrm{~km}$ 〜193 km（国鉄の距離）で，きわめて遠距離にあり，時 間にすると 30 分〜 4 時間を要する. このように大都市 とは違って，距離的な問題とともに交通網が粗であると いう時間的な制約がある特徵を有している.

\section{考察}

岩手県は本州の北東端部に位し, 総面積では全国で北 海道を除き最も広く四国 4 県に匹敵し，12市 12 郡 32 町 19 村より成り立っている，農業を主とする県である2). 本県の人口は昭和 44 年の調查で $1,371,079$ 人である が，歯科医師数は 295 人で人口 10 万対歯科医師数で は, 全国で最も少ない状態である ${ }^{3)}$. また本学の所在地 である盛岡市は，人口 189,642 人で隶科医師数は 16 人 である. 㐘池によれば，一般雪科診療の恩恵を受ける 
ことの出来ない無雨科村の住民が県人口のほぼ $1 / 7$ にあ たる 20 万 54 人もいるとのことである ${ }^{4}$.

このような立地条件にある当大学における，口腔外科 患者の動態についてみると, 外来患者数は年間を通じて 活平均しており，2,000〜3,000人であったが，これ は次第に上昇して行く傾向である.

年令別では最近の 6 カ月間の集計についてみると, 20 才代が最も多く次いで 30 才代で，20才代を中心にした ピラミッド型を呈していた，また性別では女性がやや多 く，これらは塩田の報告に類似しているよらである5).

月別にみると新患数はほぼ一定していたが，1〜3 月 にやや多い傾向がみられた．また再来患者においては変 動がみられ，1〜3 月のほか 8 月の夏休みの季節に多か ったのが特徵的で, これは当大学が農村地帯に位置し, 農閑期などの季節的変動を無視出来ない実情にあること を示している. 最近に拈いては全体的に患者数の上昇が 目立ち，とくに 7 月に多い傾向がみられた。これは前述 したように学生の臨床実習が徹底して行なわれているた めと思われる.

最近 1 年 6 カ月間の新患 4,276 名について, 疾患別 の頻度を見てみると， 5歯などの歯牙支持組織疾患が最 も多くて $56.5 \%$ も占め, さらにこれに炎症を含めると $76 \%$ とい5高率を示した. 分類方法は異なるが, 塩田 も歯牙疾患は主として歯髄炎扣よび歯根膜炎で, これが 全体 48\% のを占めていたと述べている5). 西嶋らも, ら蝕および曾周疾患が多かったといっている6)，特に炎 症については，歯牙が原因する崡槽骨炎が多く，塩田の $7.2 \%$ に対して私達の成績では $8.0 \%$ で，やや多い状態 がみられた。これらは, 当地方における慢性的な歯科医 師の不足と衛生観念の不足が，かなりの影響を及ぼして いるものと思われる.

年令的には 20 才に多かったが，このことは先に報告 した抜歯の臨床統計でも同じ結果が得られている7.

奇形については, 塩田は新来患者 15 人につき 1 人の 割合で来院しており，6.5\%を占めていたとのべている が5), 我教室では 3.1\%であった。腫瘍については悪性 腫凘は $0.6 \%$, 良性腫瘍は $1.3 \%$ であった。朱雀らは 5 年間の良性腫瘍について検討し, 外来 8,280 名中 2.73 \%にあたるとのべている8).

このように, 口腔外科を訪れる患者の疾患は種々であ り, 地域差もかなり影響するものと考えられる.ささらに 鈴木らは，医学部付属病院の棶科診療においても比較的 口腔外科手術を要求されることが多い(9) としており, こ の点からも専門機関としての菌学部口腔外科の責務は, 非常に重大なものであると思われる.

疾患別と月別の関係については, 著明な変動が炎症に おいて認められた。歯槽骨炎では 6 月と 11 月に多くみ られたのに対し, 智歯周囲炎では 1 月と 8 月に多くみら
れ，労働条件との関係や季節的な関係がらかがわれた。

当科を訪れる患者の多くは盛岡市内の在住者であった が，近郊からの来院者も多くみられた．本学矯正科の石 川らは, 来院に要する時間について $40 \%$ かi 30 分以内 のところから通院し，これには盛岡市内の患者が大部分 を占め, 残りの $60 \%$ のものが片道 30 分以上の㭙間を 費やし，なかでも $36.1 \%$ のものが 1 時間以上を要する としている(10). 矯正患者と一概に比較できないが，交通 機関の不便さによる影響がとくに強く感じられた。愛知 学院大学の報告では, 来院圈は約 $70 \%$ が 30 分 以内の ところで，バス利用者が多いのが特徽であるとされてい る ${ }^{11)}$ 。このように当科への通院患者の通院事情は, 都会 の口腔外科のそれとは非常に異なり，交通の不便な患者 に対しては時間的な束縛を受けるため, 特に入院を希望 して来科するものもかなりいる現状である. したがって 治療扣よび手術などの決定には，この点を充分考慮すべ きであると思われる.

結 論

私どもの岩手医科大学歯学部附属病院口腔外科は, 創 立後力 5 年を経過した. これを機会に外来患者の動態に ついて，とくに昭和 44 年 1 月より昭和 45 年 6 月に至 るまでの実態を調べ，今後の治療方針の手引きとなるよ らに，種々の検討を行なった．その結果地域的な特改が 十分に考えられ，特に北東北における口腔外科の専門診 療機関としての責務の重大さがうかがい知れた.

\section{文献}

1）藤阔幸婎汪か：岩手医科大学歯学部口胿外科にお㚈る㓱 設後 5 年間の入院患者の襙床的観察. 口科誌 20 : 掍械 予定 1971 .

2）岩手日報社：岩手年鑑 1971 年版, 岩手日報社, 盛间, 1971.

3） 1971 歯科医師手帳便笕，医歯薬出版，東京，1971.

4）料池万之助：へき地歯科巡回自動車計画への道. 歯界展 㕵 $25: 849 \sim 8541965$.

5) 塩田重利: 鹿児島大学医学部歯科口腔外科臨休研究会, 第 9 回症例報告, 1 年間に訪れた新来患者の統計的観察. 日本雨科評論 $293: 88 \sim 901967$.

6) 西嶋克己ほか：岡山大学医学部口舡外科教室最近 10 年 間にお汁る外来患者の臨㦿統計的観察. 日日科誌 15 ： 4341966.

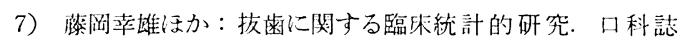
$16: 452 \sim 4671967$.

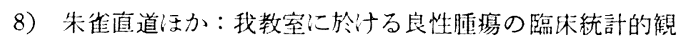
察 (抄録).日口科誌 $18: 2011969$.

9）敛木貢ほか：弘前大学医学部付属病院歯科口沿外科誩療 実態 (抄録)。日口利誌 19:413 1970 .

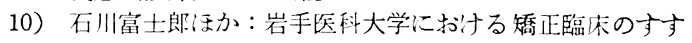
め方. 日本矯正歯科学会雔誌 $26: 63 \sim 691967$.

11）榊原悠紀田郎注か：本学付属病院に於ける新来患者の動 態. 采知学院大学楼学雑誌 (抄録) 7:194 1969. 